\title{
POT EXPERIMENT TO STUDY THE UPTAKE OF CD AND PB BY THREE INDIAN MUSTARDS (BRASSICA JUNCEA) GROWN IN ARTIFICIALLY CONTAMINATED SOILS
}

\author{
Hung-Yu Lai, ${ }^{1}$ Shih-Wen Chen, ${ }^{2}$ and Zueng-Sang Chen ${ }^{2}$ \\ ${ }^{1}$ Department of Post-Modern Agriculture, MingDao University, \\ Changhua, Taiwan \\ ${ }^{2}$ Department of Agricultural Chemistry, National Taiwan University, \\ Taipei, Taiwan
}

Most of the metals-contaminated and fallow lands in Taiwan are a result of irrigation with illegal effluent of factories. Phytoextraction methods can be applied to reach the target of fallow-lands reuse and earn more incomes for farmers. In many studies, Indian mustards (Brassica juncea) were planted in the metal-contaminated soils to study their suitability in phytoextraction. However, the total removal of metals by plants was quite different between accessions. In this pot study, three accessions of B. juncea (cv. 182921, cv. 211000, and cv. 426308) were planted in artificially $\mathrm{Cd}$ - or Pb-contaminated soils to investigate the differences between them. EDTA was applied to study its effect in increasing the bioavailability of $\mathrm{Cd}$ and $\mathrm{Pb}$ and their uptake by these Indian mustards. Experimental result showed that three accessions of Indian mustard can accumulate a high concentration of $\mathrm{Cd}$ and $\mathrm{Pb}$ when growing in the artificially $\mathrm{Cd}$ - and Pb-contaminated soils. Their shoot $\mathrm{Cd}$ or $\mathrm{Pb}$ concentrations were significantly enhanced, resulting from the application of EDTA. Among the three accessions, B. juncea $c v .211000$ accumulated the highest concentrations of Cd and $\mathrm{Pb}$ in their shoots compared with B. juncea $c v .182921$ and $c v .426308$, but its total removal was the lowest due to its lower biomass.

KEY WORDS: metals-contaminated soils, phytoextraction, Indian mustard, $\mathrm{Cd}, \mathrm{Pb}$

\section{INTRODUCTION}

Phytoextraction is a soil cleanup technology that uses the ability of metalaccumulating plants to extract metals from contaminated soil with their roots and to concentrate these metals in above-ground plant parts (Chaney et al., 1997; Lai and Chen, 2004, 2005, 2006, 2007; Salt et al., 1995). The metal-accumulating plant material can be safely harvested and removed from the site without the extensive excavation, disposal costs, and loss of topsoil associated with traditional remediation practices. The success of phytoextraction is dependent on several factors, including the availability of metals in the soil to plant. Several workers using chemical agents (such as EDTA, EDDS, NTA, and

Address correspondence to Zueng-Sang Chen, Department of Agricultural Chemistry, National Taiwan University, No. 1, Sec. 4, Roosevelt Rd., Taipei 10617, Taiwan. E-mail: soilchen@ntu.edu.tw 
CA, etc.) to enhance the availability of metals and subsequently their uptake by the plants are called induced phytoremediation (Huang et al., 1997; Lai and Chen, 2004, 2005, 2006, 2007; Tandy, Schulin, and Nowack, 2006). These agents significantly increase the uptake of metals and thus decrease the period needed for remediation. Some of the chelating agents (i.e., EDTA and HEDTA) were resisted the decomposition by organisms or microorganism. For example, results of previous studies have shown that the EDTA-metal complexes can exist in water-soluble forms for many months (Lombi et al., 2001; Means, Kucak, and Crerar, 1980; Meers et al., 2005). Although these complexes can be adsorbed by soil particles, soils that have a sandy texture or a groundwater table that has a low depth may have a high risk of groundwater contamination.

Several species of garden flowers were planted in the metals-contaminated soils of northern Taiwan approximately 20 years ago to assess the phytoextraction capacity of marketable plants (Chen and Lee, 1997). Researchers found that some of these garden flowers could accumulate a high concentration of metals in their shoots without showing any withered symptoms. When rainbow pink (Dianthus chinensis), one of the garden flowers used, was grown in a Cd-contaminated site in northern Taiwan for a period of 5 weeks. These plants accumulated $115 \mathrm{mg} \mathrm{kg}^{-1}$ of $\mathrm{Cd}$ in their shoots, which is a 73.7-fold increases in comparison to conditions before planting. Cadmium concentration in the shoots of rainbow pink can reach the threshold $\left(100 \mathrm{mg} \mathrm{Cd} \mathrm{kg}^{-1}\right)$ of a $\mathrm{Cd}$ hyperaccumulator proposed by Baker et al. (2000). From the result an in-situ experiment, rainbow pink was demonstrated and used for the phytoextraction of Cd-contaminated soil in Taiwan. Due to the low biomass of this hyperaccumulator compared with normal plants, some studies used high-biomass plants to increase the uptake of metals (Ebbs et al., 1997; Huang et al., 1997; Tandy et al., 2006; Wu, Hsu, and Cunningham, 1999). These plants include corns, sunflowers, and Indian mustards. Among these three plants used in previous studies, Indian mustards could accumulate high Cd concentration in their shoots when growing in the artificially Cd-contaminated soils (Dushenkov et al., 1995; Ebbs et al., 1997; Guo and Marschner, 1995; Kumar et al., 1995). The uptake capacity of Cd of different accessions of Indian mustards was not identical even when grown in the same metal-contaminated soil. However, only one accession of Indian mustards was used in each study to investigate their uptake of metals in enhanced phytoextraction (Irtelli and Navari-Izzo, 2006; Jiang et al., 2003; Quartacci et al., 2006; Van Engelen et al., 2007; Vassil et al., 1998; Wu et al., 2004).

The objective of this study was to compare the differences in phytoextraction capacity between three accessions of B. juncea (cv. 182921, cv. 211000, and cv. 426308) grown on artificially $\mathrm{Cd}$ - or $\mathrm{Pb}$-contaminated soils in Taiwan. Emphasis was also put on the accumulation of metals and its translocation pattern in plants with and without the application of EDTA.

\section{MATERIALS AND METHODS}

\section{Soil Characteristics}

The Cd-contaminated soils $(0-20 \mathrm{~cm})$ used in this pot experiment were collected from the northern part of Taiwan, and the contamination was due to the continuous irrigation of metals-contaminated wastewater. The samples were air dried, ground, passed through a 2-mm sieve, and stored in plastic vessel for further analysis. The $\mathrm{pH}$ was measured using glass electrodes in a water suspension with a soil-to-water ratio of 1:1 (McLean, 1982). 
The soil's particle-size distribution was measured using a pipette method (Gee and Bauder, 1986). Organic carbon was determined by using the Walkley-Black wet combustion method (Nelson and Sommers, 1982) and the cation exchange capacity (CEC) was measured using the ammonium acetate method (Rhoades, 1982). For total metals analysis, soil was digested in aqua regia. Digested samples were filtered with Whatman filter papers (No. 42, Whatman International Ltd., England) and analyzed with an atomic absorption spectrometer (AAS) (Hitachi 180-30 type Hitachi Ltd., USA) for metals analysis (EPA/ROC, 2002).

\section{Phytoextraction Capacity of Indian Mustards}

Soils used for the pot experiment to study the phytoextraction capacity of three Indian mustards were sampled from the same $\mathrm{Cd}$-contaminated site as described in the soil characteristics section and artificially added with solutions of $\mathrm{Cd}\left(\mathrm{NO}_{3}\right)_{2} \cdot 4 \mathrm{H}_{2} \mathrm{O}$ or $\mathrm{Pb}\left(\mathrm{NO}_{3}\right)_{2}$ to make the total concentration 25 and $50 \mathrm{mg} \mathrm{Cd} \mathrm{kg}^{-1}$ (coded as $\mathrm{Cd} 25$ and $\mathrm{Cd} 50$ ) or 500 and $1,000 \mathrm{mg} \mathrm{Pb} \mathrm{kg}^{-1}$ (coded as $\mathrm{Pb} 500$ and $\mathrm{Pb} 1000$ ), respectively (as individual element concentration). Each pot $(16 \mathrm{~cm}$ in diameter and $19 \mathrm{~cm}$ in height) contained 3 $\mathrm{kg}$ (dry weight) of artificially $\mathrm{Cd}$ - or Pb-contaminated soils and then 15 seeds for each $B$. juncea (cv. 182921, cv. 211000, and cv. 426308) taken from the United States Department of Agriculture Northern Central Regional Plant Introduction Station were sown in each pot. Two rhizosphere soil moisture samplers (RSMS; Eijkelkamp Agrisearch Equipment Comp., The Netherlands) were put in each pot at a depth of approximately $10 \mathrm{~cm}$ below the soil surface. The pot experiment was conducted in the phytotron $\left(\right.$ day $/$ night $=30 / 25^{\circ} \mathrm{C}$ ) with three replicates and kept with soil's water content at $60 \%$ of the water-holding capacity (WHC) by adding deionized water every $2 \mathrm{~d}$. After germination, we kept five seedlings in each pot and removed surplus seedlings because the diameter of each pot is only 16 $\mathrm{cm}$. After growing for $35 \mathrm{~d}$, the shoots of plants were harvested, rinsed with tap water and deionized water, oven dried at $60^{\circ} \mathrm{C}$ for $72 \mathrm{~h}$, ground into $<0.5 \mathrm{~mm}$, digested with the $\mathrm{H}_{2} \mathrm{SO}_{4} / \mathrm{H}_{2} \mathrm{O}_{2}$ method (Harmon and Lajtha, 1999), and then used to determined for the $\mathrm{Cd}$ and $\mathrm{Pb}$ concentrations with an AAS (Hitachi 180-30 type).

In another experiment, 15 seeds of the same $B$. juncea were sown in the pot, in soils that were artificially contaminated withCd- or $\mathrm{Pb}$ as described above. The pot experiment was conducted in the phytotron (day/night $=30 / 25^{\circ} \mathrm{C}$ ) with three replicates and at $60 \%$ of WHC by adding deionized water every $2 \mathrm{~d}$. After germination, five seedlings were kept in each pot and the surplus seedlings were removed. Solutions of 5 mmol EDTA $\mathrm{kg}^{-1}$ soil were applied to each pot after growing for $28 \mathrm{~d}$. The shoots of plants were harvested at day 7 after applying EDTA and then treated with the same procedures as described above to determine the $\mathrm{Cd}$ or $\mathrm{Pb}$ in the shoots of plants. Soil solutions before seeding and at days 7, 14, 21, 28, and 35 after seeding were sampled with RSMS and the $\mathrm{Cd}$ and $\mathrm{Pb}$ concentrations were determined with an ICP/OES (Perkin Elmer 2000DV, Perkin Elmer, Inc., USA).

\section{Statistics}

The variance and significance of the differences among concentrations of $\mathrm{Cd}$ and $\mathrm{Pb}$ in the soil solutions and in the plants were analyzed by analysis of variance. Statistical significance was defined as the level of $p=0.05$. 


\section{RESULTS AND DISCUSSION}

\section{Soil Characteristics}

The soil texture was silty clay with a moderate CEC of $13.9 \mathrm{cmol}_{(+)} \mathrm{kg}^{-1}$ soil, its $\mathrm{pH}$ was 4.9 and the organic carbon was $16.9 \mathrm{~g} \mathrm{~kg}^{-1}$. The initial un-contaminated total metal concentrations $\left(\mathrm{mg} \mathrm{kg}^{-1}\right)$ in the contaminated soil were $2.58 \pm 0.08(\mathrm{Cd}), 80.0 \pm 5.3(\mathrm{Zn})$, and $31.3 \pm 2.1(\mathrm{~Pb})$, respectively.

\section{Phytoextraction Capacity of Indian Mustards}

Tables 1 and 2 show the concentrations of $\mathrm{Cd}$ and $\mathrm{Pb}$ in the soil solution or in soil extracted with different extractants in $\mathrm{Cd}$ - or Pb-contaminated soils. For these soils, $0.05 \mathrm{M}$ EDTA and 0.005 M DTPA could extract approximately 55-96\% and 65-90\% of the total $\mathrm{Cd}$ and $\mathrm{Pb}$ concentration determined with aqua regia method. Those fractions of $\mathrm{Cd}$ and $\mathrm{Pb}$ in soil extracted by EDTA and DTPA were available for plant uptake (Kabata-Pendias and Pendias, 2001). The results revealed that these two extracts may have a strong capacity for extracting the metals in artificially contaminated soils or that most of the $\mathrm{Cd}$ and $\mathrm{Pb}$ in the study soil were in the labile fractions.

After growing in the initial soil (control treatment of $\mathrm{Cd}$ ) for $35 \mathrm{~d}$, the shoot $\mathrm{Cd}$ concentrations in three Indian mustards ranged from 38 to $44 \mathrm{mg} \mathrm{kg}^{-1}$ (Figure 1) with transfer coefficients (TC; metal concentration ratio of shoot/soil) of 12-14. Results showed that after growing in the artificially Cd-contaminated soils $(\mathrm{Cd} 25,50)$ for $35 \mathrm{~d}$, different Indian mustards could accumulate $120-210 \mathrm{mg} \mathrm{Cd} \mathrm{kg}^{-1}$ in their shoots and that there was no significant difference between three accessions (Figure 1). However, their TC value decreased from 12-14 (initial soil) to 3.4-6.2 (Cd 25, 50). The accumulated concentration of $\mathrm{Cd}$ in Indian mustards was approximately 4- to 6-fold higher than earlier reported by $\mathrm{Wu}$

Table $1 \mathrm{Cd}$ concentration in soil solution and in soil digested with aqua regia, or extracted by $0.05 \mathrm{M}$ EDTA or 0.005 M DTPA after planting Indian mustards for $35 \mathrm{~d}$

\begin{tabular}{|c|c|c|c|c|}
\hline \multirow[b]{3}{*}{ Treatment } & \multicolumn{4}{|c|}{ Analytic methods } \\
\hline & \multirow{2}{*}{$\begin{array}{l}\text { Soil solution (mg } \\
\left.\qquad \mathrm{L}^{-1}\right)\end{array}$} & \multicolumn{3}{|c|}{$\mathrm{mg} \mathrm{kg}^{-1}$} \\
\hline & & Aqua regia & 0.05 M EDTA & 0.005 M DTPA \\
\hline & \multicolumn{4}{|c|}{ B. juncea cv. 182921} \\
\hline Control & $0.13 \pm 0.03$ & $3.18 \pm 0.29$ & $1.98 \pm 0.02$ & $1.72 \pm 0.02$ \\
\hline $\mathrm{Cd} 25$ & $0.75 \pm 0.21$ & $25.0 \pm 1.0$ & $22.7 \pm 0.9$ & $20.2 \pm 1.0$ \\
\hline \multirow[t]{2}{*}{$\mathrm{Cd} 50$} & $0.98 \pm 0.10$ & $49.0 \pm 2.5$ & $46.9 \pm 3.2$ & $41.3 \pm 3.7$ \\
\hline & \multicolumn{4}{|c|}{ B. juncea cv. 211000} \\
\hline Control & $0.10 \pm 0.02$ & $3.24 \pm 0.18$ & $2.04 \pm 0.44$ & $1.76 \pm 0.03$ \\
\hline $\mathrm{Cd} 25$ & $0.77 \pm 0.09$ & $27.1 \pm 0.6$ & $24.3 \pm 0.5$ & $21.7 \pm 0.4$ \\
\hline \multirow[t]{2}{*}{$\mathrm{Cd} 50$} & $0.92 \pm 0.30$ & $49.4 \pm 0.6$ & $44.0 \pm 2.1$ & $40.2 \pm 0.6$ \\
\hline & \multicolumn{4}{|c|}{ B. juncea cv. 426308} \\
\hline Control & $0.07 \pm 0.02$ & $3.18 \pm 0.14$ & $2.22 \pm 0.05$ & $1.42 \pm 0.03$ \\
\hline $\mathrm{Cd} 25$ & $0.92 \pm 0.69$ & $28.4 \pm 1.3$ & $19.6 \pm 5.8$ & $17.5 \pm 0.6$ \\
\hline $\mathrm{Cd} 50$ & $1.16 \pm 1.09$ & $51.8 \pm 3.7$ & $28.3 \pm 2.7$ & $36.1 \pm 3.4$ \\
\hline
\end{tabular}

\footnotetext{
${ }^{\#}:$ mean \pm standard deviation $(n=3)$.
} 
Table $2 \mathrm{~Pb}$ concentration in soil solution and in soil digested with aqua regia, or extracted by $0.05 \mathrm{M}$ EDTA or 0.005 M DTPA after planting Indian mustards for $35 \mathrm{~d}$

\begin{tabular}{|c|c|c|c|c|}
\hline \multirow[b]{3}{*}{ Treatment } & \multicolumn{4}{|c|}{ Analytic methods } \\
\hline & \multirow[b]{2}{*}{$\begin{array}{l}\text { Soil solution (mg } \\
\left.\qquad \mathrm{L}^{-1}\right)\end{array}$} & \multicolumn{3}{|c|}{$\mathrm{mg} \mathrm{kg}^{-1}$} \\
\hline & & Aqua regia & $0.05 \mathrm{M}$ EDTA & 0.005 M DTPA \\
\hline & \multicolumn{4}{|c|}{ B. juncea cv. 182921} \\
\hline Control & $0.02 \pm 0.01^{\#}$ & $38.7 \pm 2.0$ & $9.13 \pm 0.17$ & $6.55 \pm 0.07$ \\
\hline $\mathrm{Pb} 500$ & $1.35 \pm 0.33$ & $604 \pm 5$ & $529 \pm 14$ & $443 \pm 11$ \\
\hline \multirow[t]{2}{*}{$\mathrm{Pb} 1000$} & $2.32 \pm 0.44$ & $1159 \pm 34$ & $1033 \pm 20$ & $888 \pm 8$ \\
\hline & \multicolumn{4}{|c|}{ B. juncea cv. 211000} \\
\hline Control & $0.02 \pm 0.01$ & $35.5 \pm 2.4$ & $10.3 \pm 1.3$ & $6.54 \pm 1.90$ \\
\hline $\mathrm{Pb} 500$ & $1.58 \pm 0.30$ & $612 \pm 7$ & $537 \pm 29$ & $466 \pm 28$ \\
\hline \multirow[t]{2}{*}{$\mathrm{Pb} 1000$} & $3.26 \pm 0.93$ & $1197 \pm 12$ & $1072 \pm 9$ & $827 \pm 60$ \\
\hline & \multicolumn{4}{|c|}{ B. juncea cv. 426308} \\
\hline Control & $0.03 \pm 0.01$ & $35.0 \pm 1.4$ & $10.2 \pm 0.4$ & $5.74 \pm 0.30$ \\
\hline $\mathrm{Pb} 500$ & $1.06 \pm 0.23$ & $604 \pm 10$ & $537 \pm 11$ & $410 \pm 16$ \\
\hline $\mathrm{Pb} 1000$ & $3.04 \pm 1.67$ & $1249 \pm 1$ & $1000 \pm 200$ & $807 \pm 175$ \\
\hline
\end{tabular}

\#:mean \pm standard deviation $(n=3)$.

et al. (2004) and can reach the threshold (100 $\mathrm{mg} \mathrm{kg}^{-1}$ ) of a Cd hyperaccumulator (Baker et al., 2000). Figure 2 shows the accumulated concentration of $\mathrm{Pb}$ in the shoots of three Indian mustards after growing in the artificially Pb-treated soils $(\mathrm{Pb} 500,1000)$ for $35 \mathrm{~d}$. In the initial soil without artificially spiked $\mathrm{Pb}$, the $\mathrm{Pb}$ concentration in soil solutions was low

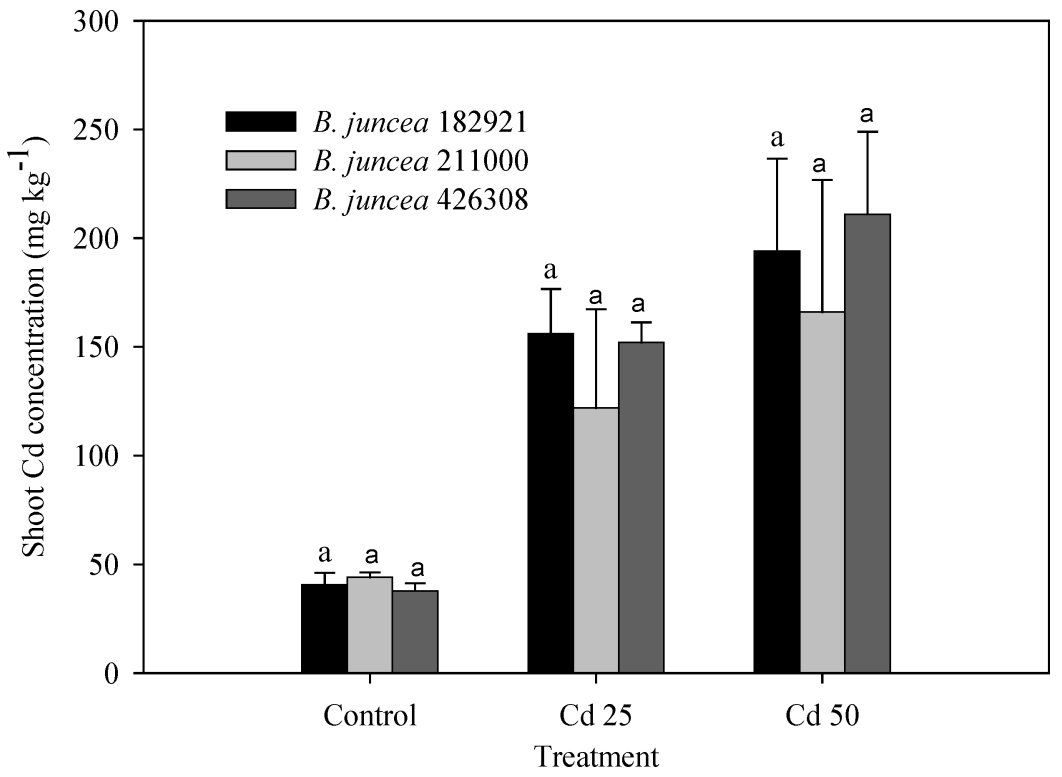

Figure 1 Shoot Cd concentration of three accessions of Indian mustard, which were harvested at day 35 after planting in the artificially Cd-contaminated soils. The probability level of significant difference is at $p=0.05$. Replicates $(n)=3$. 


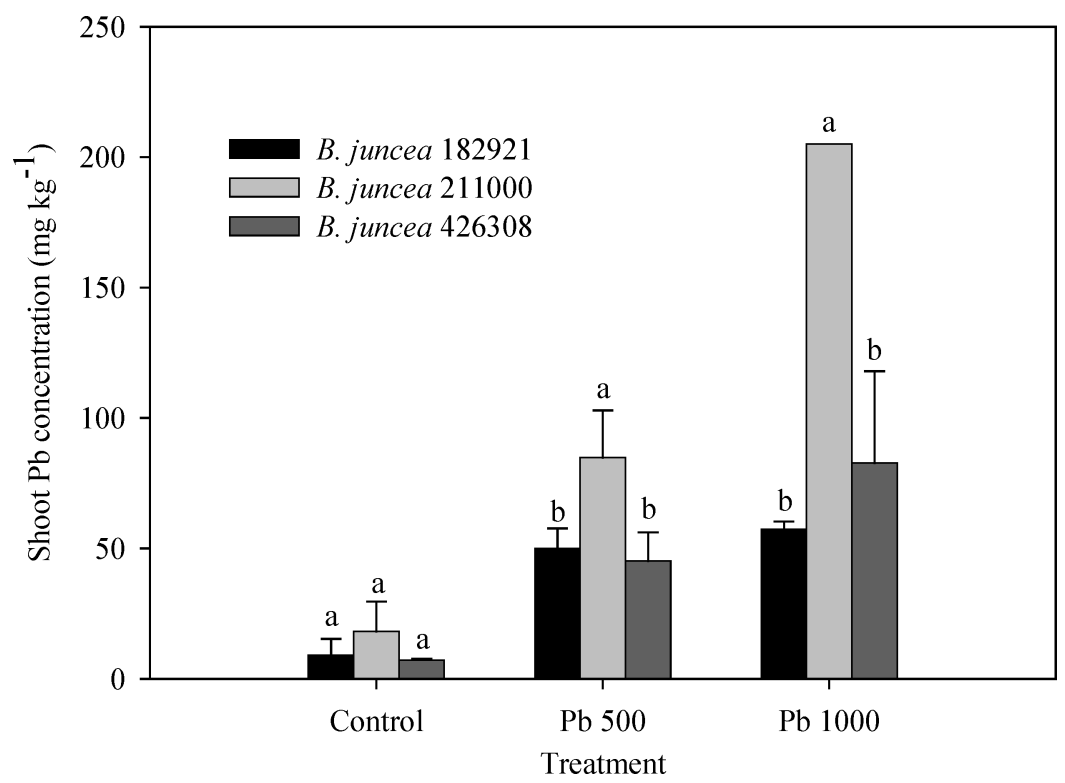

Figure 2 Shoot $\mathrm{Pb}$ concentration of three accessions of Indian mustard, which were harvested at day 35 after planting in the artificially $\mathrm{Pb}$-contaminated soils. The probability level of significant difference is at $p=0.05$. Replicates $(n)=3$.

relative to the total concentration in soil. Both of the 0.05 M EDTA and 0.005 M DTPA extractable $\mathrm{Pb}$ concentration were $<30 \%$ of the total $\mathrm{Pb}$ concentration as determined by using the aqua regia method. Lead concentration in the shoots of Indian mustards was $<20 \mathrm{mg} \mathrm{kg}^{-1}$ with TC values of $0.2-0.6$ due to its low availability in the initial soil. After planting in $\mathrm{Pb} 500$ and $\mathrm{Pb} 1000$ for $35 \mathrm{~d}$, these Indian mustards could accumulate 45-210 $\mathrm{mg} \mathrm{Pb} \mathrm{kg}{ }^{-1}$ in their shoots and $B$. juncea $\mathrm{cv} .211000$ had the highest $\mathrm{Pb}$ concentration ( $p$ $<0.05$ ) in their shoots among these three accessions (Figure 2). However, their TC values were all $<0.2$ due to its low concentration in soil solution relative to the total concentration in artificially $\mathrm{Pb}$-contaminated soil.

There are good relationships between the $\mathrm{Cd}$ or $\mathrm{Pb}$ concentrations in soil solutions and those in the shoots of Indian mustards. The correlation coefficient $(r)$ between the concentrations of $\mathrm{Cd}$ and $\mathrm{Pb}$ in the soil solutions and those in the shoots of Indian mustards was $0.77-0.82(p<0.001)$ and $0.92-0.93(p<0.001)$, respectively. There are good relationships between the $\mathrm{Cd}$ or $\mathrm{Pb}$ concentrations in soils extracted by $0.05 \mathrm{M}$ EDTA or $0.005 \mathrm{M}$ DTPA and those accumulated in the shoots of Indian mustards. The correlation coefficient $(r)$ of shoot $\mathrm{Cd}$ versus $0.05 \mathrm{M}$ EDTA and 0.005 M DTPA extractable Cd was in the range of $0.87-0.94$ and $0.90-0.94(p<0.001)$. The correlation coefficient $(r)$ of shoot $\mathrm{Pb}$ versus $0.05 \mathrm{M}$ EDTA and $0.005 \mathrm{M}$ DTPA extractable $\mathrm{Pb}$ was in the range of $0.88-0.95$ and $0.88-0.94(p<0.001)$. The result of this study shows that soil solution, 0.05 M EDTA, and $0.005 \mathrm{M}$ DTPA were suitable methods for predicting the accumulated Cd or $\mathrm{Pb}$ concentration in the shoots of Indian mustards.

\section{EDTA-Enhanced Phytoextraction of Indian Mustards}

The concentrations of $\mathrm{Cd}$ (Figure 3) and $\mathrm{Pb}$ (Figure 4) in the soil solutions of artificially $\mathrm{Cd}$ - or $\mathrm{Pb}$-contaminated soil were significantly $(p<0.05)$ increased with the 

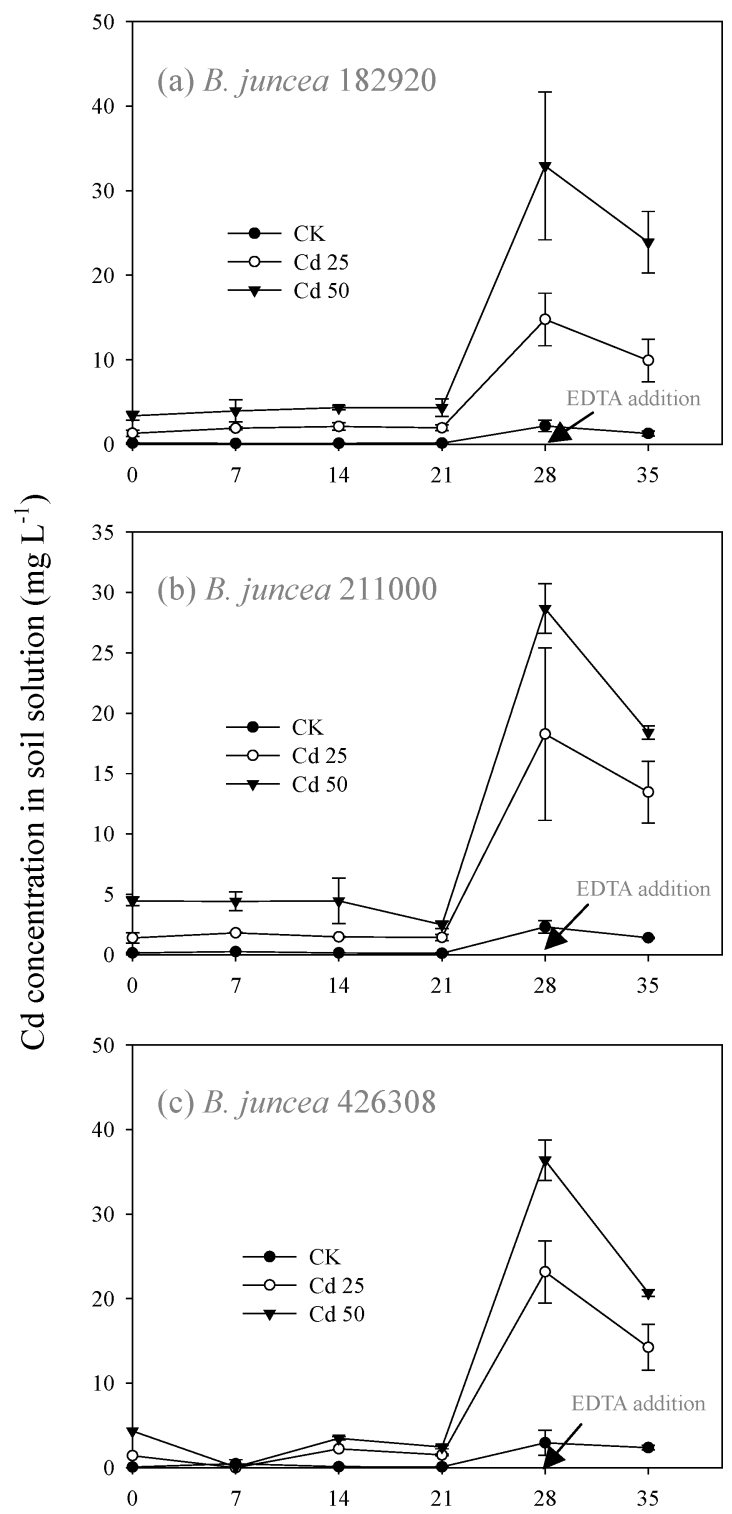

Duration after seeding (d)

Figure 3 Change of Cd concentrations in soil solutions of artificially Cd-contaminated soils. Three accessions of Indian mustard were harvested at day 7 after applying 5 mmol EDTA kg${ }^{-1}$ soil. Replicates $(n)=3$.

application of 5 mmol EDTA kg$~^{-1}$ soil. The application of EDTA significantly $(p<0.05)$ increased the $\mathrm{Cd}$ concentrations $\left(\mathrm{mg} \mathrm{L}^{-1}\right)$ in the soil solutions of both the treatments from $1.2-1.5$ and 3.3-4.5 to 14-24 and 28-37 (the increase was approximately 6.5- to 17-fold). Lead concentrations in the soil solutions were also found to be significantly $(p<0.05)$ increased in both the treatment of $\mathrm{Pb}$ (500 and 1000) from 1.6-2.1 and 4.9-5.2 to 480-580 and 570-880 (the increase was approximately 110- to 320-fold). Several reports are in 


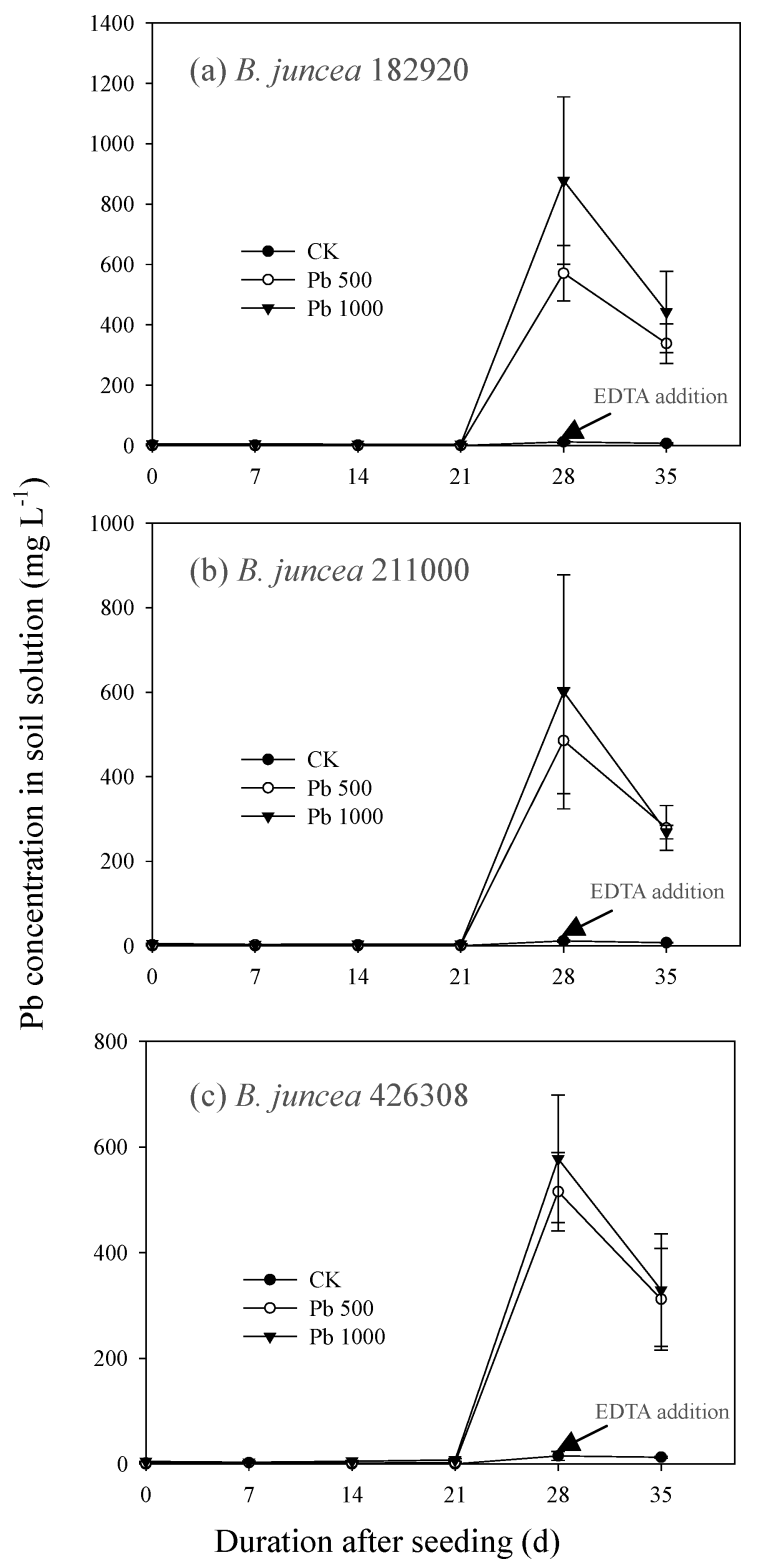

Figure 4 Change of $\mathrm{Pb}$ concentrations in soil solutions of artificially $\mathrm{Pb}$-contaminated soils. Three accessions of Indian mustard were harvested at day 7 after applying 5 mmol EDTA kg ${ }^{-1}$ soil. $\operatorname{Replicates}(n)=3$.

agreement with findings in this study (Huang et al., 1997; Lai and Chen, 2004, 2005, 2006, 2007). The enhancement effect due to applying EDTA on Pb concentration in the soil solution was better than $\mathrm{Cd}$ due to the greater formation constant of EDTA-Pb $\left(\log K_{f}=\right.$ 19.0) relative to EDTA-Cd $\left(\log K_{f}=17.4\right)$. However, the high $\mathrm{Cd}$ and $\mathrm{Pb}$ concentrations in soil solutions resulted from the application of 5 mmol EDTA $\mathrm{kg}^{-1}$ soil, which have a high potential for groundwater contamination (Jiang et al., 2003; Lai and Chen, 2007). 

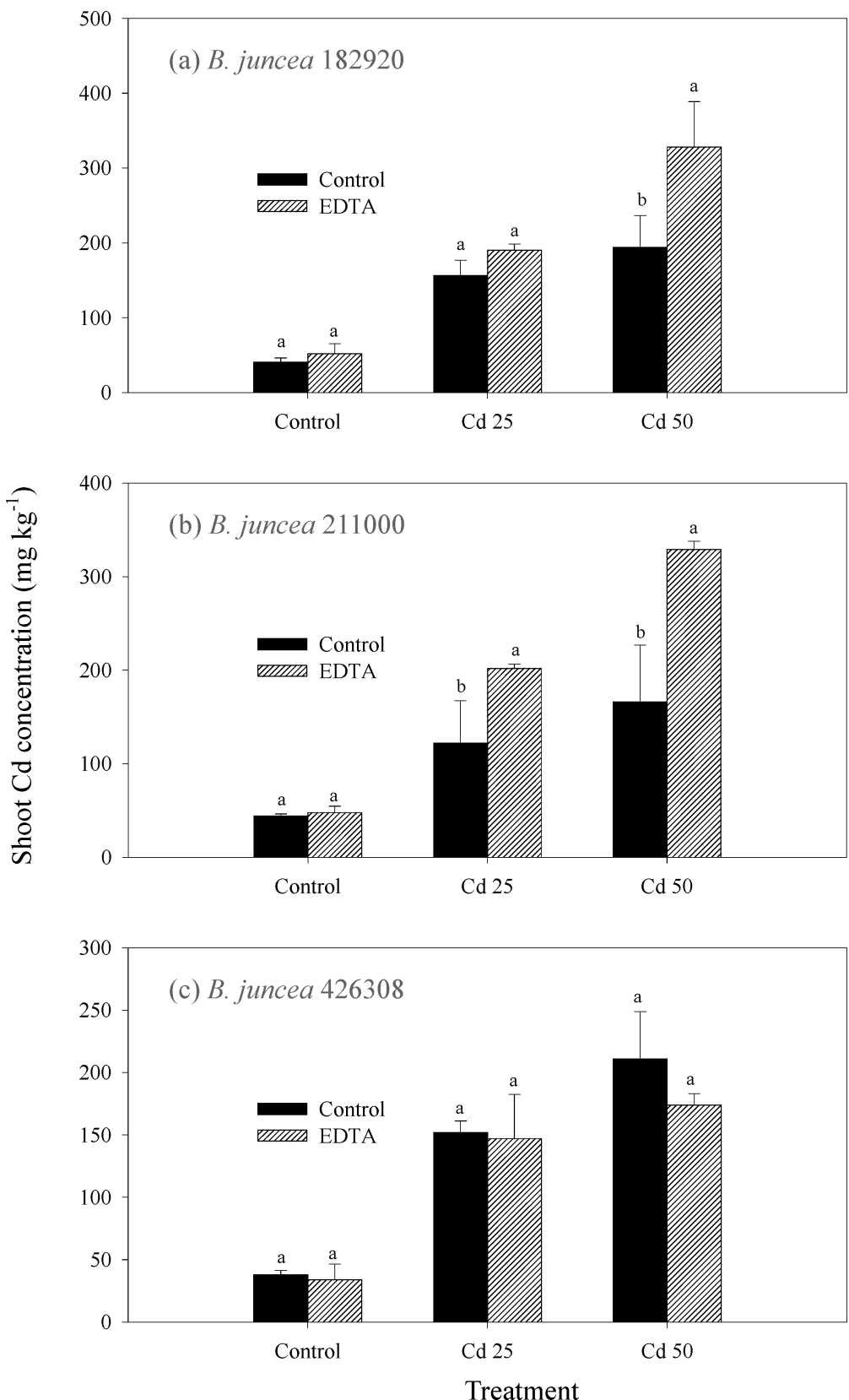

Figure 5 Comparisons of Cd concentrations in the shoot of three accessions of Indian mustard, which were harvested at day 7 after applying 5 mmol EDTA $\mathrm{kg}^{-1}$ soil. The probability level of significant difference is at $p$ $=0.05$. Replicates $(n)=3$.

The application of $5 \mathrm{mmol}$ EDTA $\mathrm{kg}^{-1}$ soil significantly increased the $\mathrm{Cd}$ concentration in the shoots of B. juncea cv. 211000 (Figure 5) $(p<0.05)$. Their shoot $\mathrm{Cd}$ concentrations, when grown in $\mathrm{Cd} 25$ and $\mathrm{Cd} 50$, were significantly increased from 

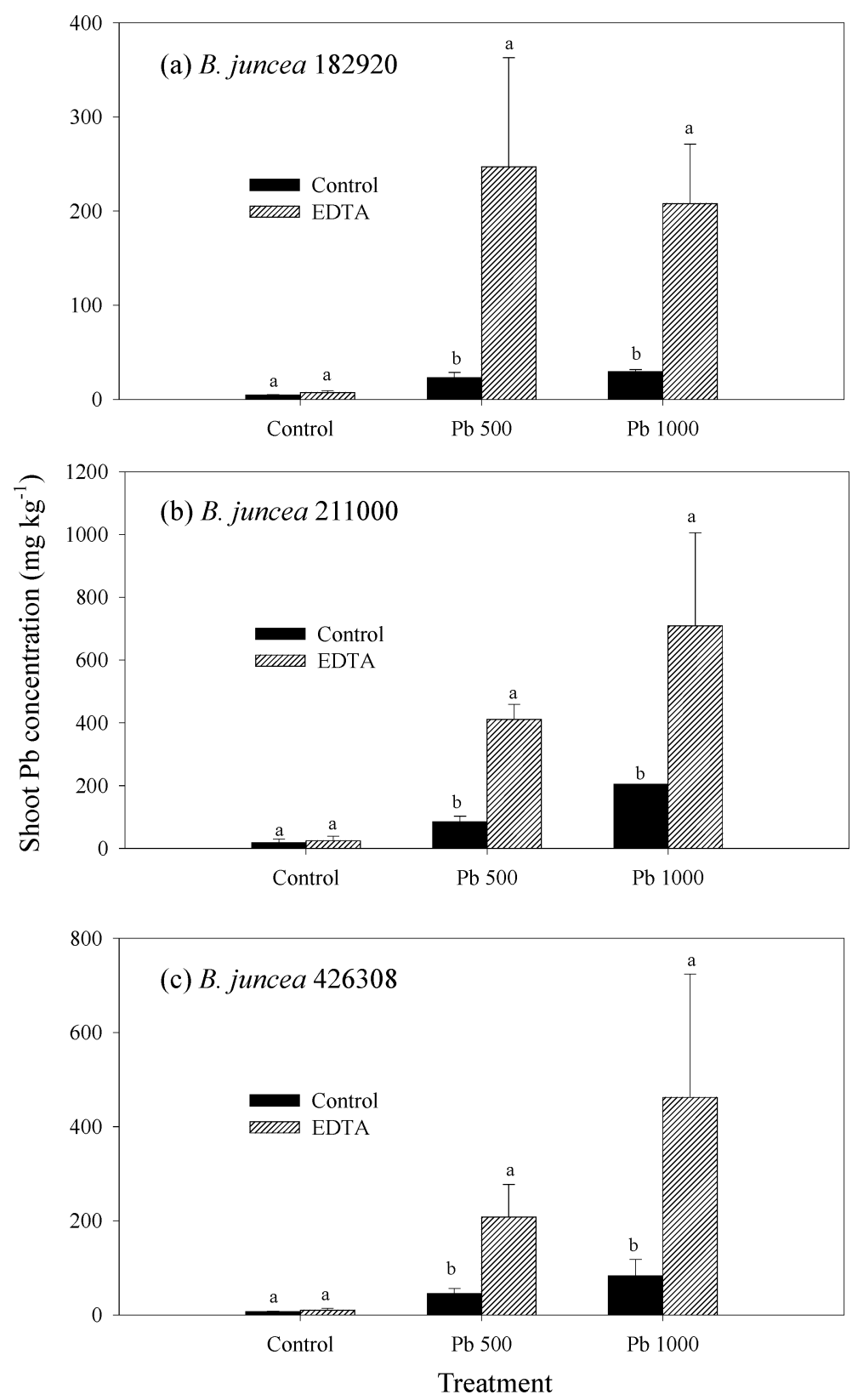

Figure 6 Comparisons of the $\mathrm{Pb}$ concentrations in the shoots of three accessions of Indian mustard, which were harvested at day 7 after applying $5 \mathrm{mmol}$ EDTA $\mathrm{kg}^{-1}$ soil. The probability level of significant difference is at $p$ $=0.05$. Replicates $(n)=3$.

approximately $120-170$ (without EDTA) to $200-330 \mathrm{mg} \mathrm{kg}^{-1}$ after applying EDTA ( $p$ $<0.05$ ) (Figure 5b). Because the Pb concentration in the soil solution was significantly increased after applying EDTA (Figure 4), the concentration accumulated in the shoots of three accessions of Indian mustard also significantly $(p<0.05)$ increased from 40-210 

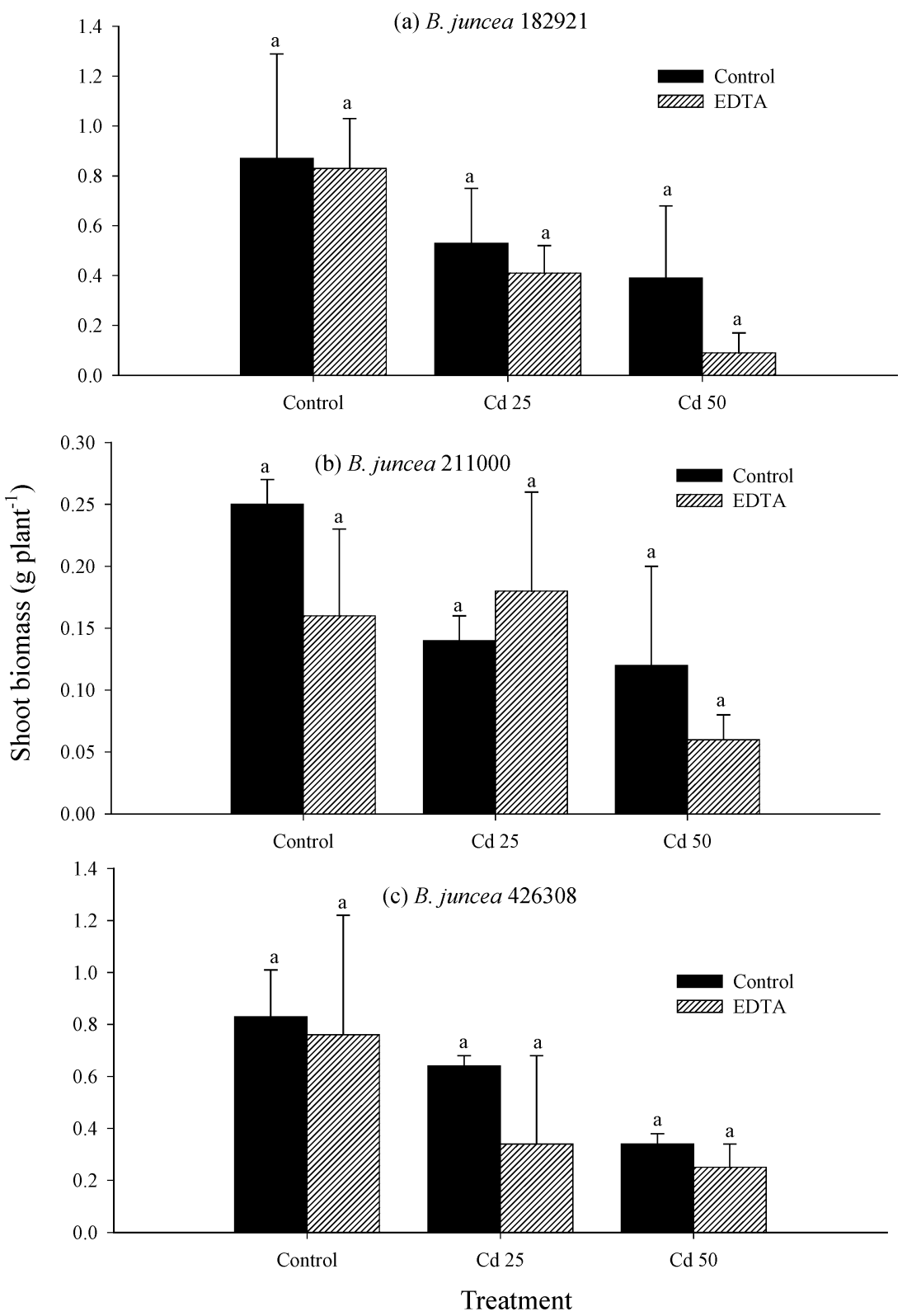

Figure 7 Comparisons of the biomass of three accessions of Indian mustard, which were grown in the artificially Cd-contaminated soils and harvested at day 7 after applying 5 mmol EDTA kg ${ }^{-1}$ soil. The probability level of significant difference is at $p=0.05$. Replicates $(n)=3$.

(without EDTA) to 200-710 $\mathrm{mg} \mathrm{kg}^{-1}$ (in the EDTA treatment) (Figure 6). Compared with the other two accessions of Indian mustard, B. juncea cv. 211000 had higher uptake for $\mathrm{Pb}$ when grown in the $\mathrm{Pb} 500$ and $\mathrm{Pb} 1000$ with or without EDTA applied. However, it had lower biomass relative to B. juncea cv. 182921 and cv. 426308 (Figures 7 and 8) and thus had lower total removal of $\mathrm{Cd}$ and $\mathrm{Pb}$ when grown in the artificially $\mathrm{Cd}$ - or 

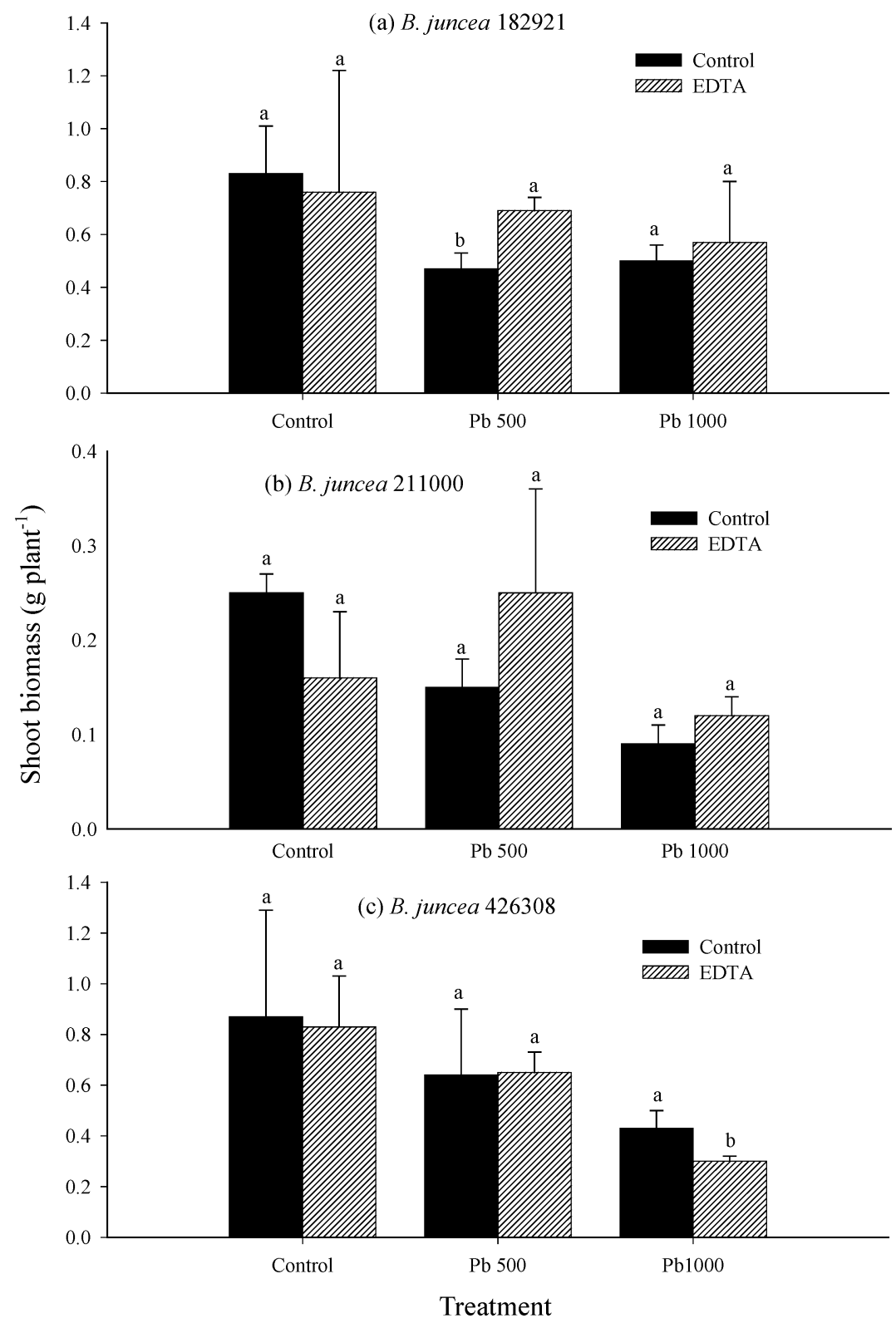

Figure 8 Comparisons of the biomass of three accessions of Indian mustard, which were grown in the artificially $\mathrm{Pb}$-contaminated soils and harvested at day 7 after applying 5 mmol EDTA kg ${ }^{-1}$ soil. The probability level of significant difference is at $p=0.05$. Replicates $(n)=3$.

$\mathrm{Pb}$-contaminated soils with or without EDTA applied. For most of the Indian mustards grown in the artificially $\mathrm{Cd}$ - or $\mathrm{Pb}$-contaminated soils, the effect of applying $5 \mathrm{mmol}$ EDTA $\mathrm{kg}^{-1}$ soil on their biomass was not identical (Figures 7 and 8). EDTA seems to have had an adverse effect on the shoot biomass of Indian mustards grown in the Cd-contaminated soils, but the effect was not significant (Figure 7). The adverse effect of EDTA on the growth 
of Indian mustards was also reported by previous studies (Jiang et al., 2003; Van Engelen et al., 2007).

EDTA-induced phytoextraction of three accessions of Indian mustards showed that the $\mathrm{Cd}$ and $\mathrm{Pb}$ concentrations in the soil solutions were significantly $(p<0.05)$ increased after applying $5 \mathrm{mmol}$ of EDTA $\mathrm{kg}^{-1}$ soil, especially for $\mathrm{Pb}$. Although no leaching experiment was conducted in this study, the results of many researches have shown that the highly soluble concentration of metals after applying EDTA had the potential risk of impacting groundwater quality in sandy textural soils (Jiang et al., 2003; Lai and Chen, 2007; Van Engelen et al., 2007; Wu et al., 2004). Biodegradable chelating agents, EDDS, were recommended by many researchers to be a substitute for EDTA (Luo et al., 2006; Meers et al., 2005; Tandy et al., 2006). The increase of available fractions of Cd and $\mathrm{Pb}$ in soils after applying EDTA resulted in a significantly increased uptake in Indian mustards. Among the three accessions of Indian mustard used in this study, B. juncea cv. 211000 could accumulate higher concentration of $\mathrm{Pb}$ after growing in the artificially $\mathrm{Pb}$-contaminated soils $\left(500\right.$ and $1,000 \mathrm{mg} \mathrm{kg}^{-1}$ ) for $35 \mathrm{~d}$ with or without applying EDTA as compared with $B$. juncea cv. 182921 and cv. 426308. However, its total removal of $\mathrm{Pb}$ was the lowest due to their lowest biomass among the three accessions.

\section{CONCLUSION}

In our opinion, the accumulated metals concentration in shoots, growing conditions, and their economic values are three major factors for selecting the plants used to phytoextract metals-contaminated soils in Taiwan. Results of a pot experiment showed that three accessions of Indian mustard can accumulate high concentration of $\mathrm{Cd}$ in their shoots without any injury. Among the three accessions of Indian mustard, B. juncea cv. 182921 and cv. 426308 removed higher amounts of $\mathrm{Cd}$ and $\mathrm{Pb}$ as compared with B. juncea cv. 211000 after growing in the artificially $\mathrm{Cd}$ - and $\mathrm{Pb}$-contaminated soils for $35 \mathrm{~d}$. They can be sown into the Cd-contaminated soils and then harvested by machine after planting for 1-2 mo. Overall, experimental results showed that three accessions of Indian mustard are suitable for phytoextraction of Cd-contaminated soils in Taiwan although their uptake capacity of $\mathrm{Cd}$ and $\mathrm{Pb}$ was different. The application of EDTA can significantly increase the metal concentration in soil solution of artificially metal-contaminated soils. However, results of previous studies showed that the high risk of groundwater contamination after applying EDTA was an unsolved problem due to the persistence of EDTA against the biodegradation of microorganism. Natural phytoextraction without applying chemical agents is a better way to treat of metal-contaminated soils as compared with EDTA-enhanced phytoextraction.

\section{ACKNOWLEDGEMENT}

The authors would like to thank the United States Department of Agriculture Northern Central Regional Plant Introduction Station for providing the seeds of three accessions of Indian mustard.

\section{REFERENCES}

Baker, A.J.M., McGrath, S.P., Reeves, R.D., and Smith, J.A.C. 2000. Metal hyperaccumulator plants: A review of the ecology and physiology of a biological resource for phytoremediation of 
metal-polluted soils. In: Phytoremediation of Contaminated Soil \& Water, pp. 85-107. (Terry, N. and Bañuelos, G., Eds.). Boca Raton, FL, CRC.

Chaney, R.L., Malik, M., Li, Y.M., Brown, S.L., Brewer, E.P., Angle, J.S., and Baker, A.J.M. 1997. Phytoremediation of soil metals. Environ. Biotechnol. 8, 279-284.

Chen, Z.S. and Lee, D.Y. 1997. Evaluation of remediation techniques on two cadmium-polluted soils in Taiwan. In: Remediation of Soils Contaminated with Metals, pp. 209-223. (Iskandar, I.K. and Adriano, D.C., Eds.). Northwood, UK: Science Reviews.

Dushenkov, V., Kumar, P.B.A.N., Motto, H., and Raskin, I. 1995. Rhizofiltration: The use of plants to remove heavy metals from aqueous streams. Environ. Sci. Technol. 29, 1239-1245.

Ebbs, S.D., Lasat, M.M., Brady, D.J., Cornish, J., Gordon, R., and Kochian, L.V. 1997. Phytoextraction of cadmium and zinc from a contaminated soil. J. Environ. Qual. 26, 1424-1430.

EPA/ROC. 2002. Method code No: NIEA S321.62C; Environmental Protection Administration of Taiwan ROC, Taipei, Taiwan.

Gee, G.W. and Bauder, J.W. 1986. Particle-size analysis. In: Methods of soil analysis, Part 1, Physical and Mineralogical Method, 2nd ed., pp. 383-412. (Klute, A., Ed.). Madison, WI, Agronomy Monograph 9.

Guo, Y. and Marschner, H. 1995. Uptake, distribution, and binding of cadmium and nickel in different plant species. J. Plant Nutr. 18, 2691-2706.

Harmon, M.E. and Lajtha, K. 1999. Analysis of detritus and organic horizons for mineral and organic constitutes. In: Standard Soil Methods for Long-Term Ecological Research, pp. 143-165. (Robertson, G.P., Coleman, D.C., Bledsoe, C.S., and Sollins, P., Eds.). New York, Oxford University Press.

Huang, J.W., Chen, J., Berti, W.R., and Cunningham, S.D. 1997. Phytoremediation of leadcontaminated soils: Role of synthetic chelates in lead phytoextraction. Environ. Sci. Technol. 31, 800-805.

Irtelli, B. and Navari-Izzo, F. 2006. Influence of sodium nitrilotriacetate (NTA) and citric acid on phenolic and organic acids in Brassica juncea grown in excess of cadmium. Chemosphere $\mathbf{6 5}$, $1348-1354$.

Jiang, X.J., Luo, Y.M., Zhao, Q.G., Baker, A.J.M., Christie, P., and Wong, M.H. 2003. Soil $\mathrm{Cd}$ availability to Indian mustard and environmental risk following EDTA addition to Cd-contaminated soil. Chemosphere 50, 813-818.

Kabata-Pendias, A. and Pendias, H. 2001. Trace elements in plants. In: Trace Element in Soils and Plants, 3rd ed., pp. 73-98. (Kabata-Pendias, A. and Pendias, H., Eds.). Boca Raton, FL, CRC.

Kumar, P.B.A.N., Dushenkov, V., Motto, H., and Raskin, I. 1995. Phytoextraction: The use of plants to remove heavy metals from soils. Environ. Sci. Technol. 29, 1232-1238.

Lai, H.Y. and Chen, Z.S. 2004. Effects of EDTA on solubility of cadmium, zinc, and lead and their uptake by rainbow pink and vetiver grass. Chemosphere 55, 421-430.

Lai, H.Y. and Chen, Z.S. 2005. The effect of EDTA on phytoextraction of single and combined metals-contaminated soils by rainbow pink. Chemosphere 60, 1062-1071.

Lai, H.Y. and Chen, Z.S. 2006. The effects of cadmium, zinc, and lead interactions on the accumulation of metals by rainbow pink. J. Hazard. Mater. 137, 1710-1718.

Lai, H.Y. and Chen, Z.S. 2007. Effects of multi-dose EDTA application on the phytoextraction of $\mathrm{Cd}, \mathrm{Zn}$, and $\mathrm{Pb}$ by rainbow pink (Dianthus chinensis) in contaminated soil. Desalination 210, 236-247.

Lombi, E., Zhao, F.J., Dunham, S.J., and McGrath, S.P. 2001. Phytoremediation of heavy metalcontaminated soils: Natural hyperaccumulation versus chemically enhanced phytoextraction. J. Environ. Qual. 30, 1919-1926.

Luo, C.L., Shen, Z.G., Lou, L.Q., and Li, X.D. 2006. EDDS and EDTA-enhanced phytoextraction of metals from artificially contaminated soil and residual effects of chelant compounds. Environ. Pollut. 144, 862-871. 
McLean, E.O. 1982. Soil pH and lime requirement. In: Methods of soil analysis, Part 2, Chemical and Microbiological Properties, 2nd ed., pp. 199-224. (Page, A.L., Ed.). Madison, WI, Agronomy Monograph 9.

Means, J.L., Kucak, T., and Crerar, D.A. 1980. Relative degradation rates of NTA, EDTA and environmental implications. Environ. Pollut. Ser. B 1, 45-60.

Meers, E., Ruttens, A., Hopgood, M.J., Samson, D., and Tack, F.M.G. 2005. Comparison of EDTA and EDDS as potential soil amendments for enhanced phytoextraction of heavy metals. Chemosphere 58, 1011-1022.

Nelson, D.W. and Sommers, L.E. 1982. Total carbon, organic carbon, and organic matter. In: Methods of Soil Analysis, Part 2, Chemical and Microbiological Properties, 2nd ed., pp. 539-580. (Page, A.L., Ed.). Madison, WI, Agronomy Monograph 9.

Quartacci, M.F., Argilla, A., Baker, A.J.M., and Navari-Izzo, F. 2006. Phytoextraction of metals from a multiply contaminated soil by Indian mustard. Chemosphere 63, 918-925.

Rhoades, J.K. 1982. Cation exchange capacity. In: Methods of Soil Analysis, Part 2, Chemical and Microbiological Properties, 2nd ed., pp. 149-158. (Page, A.L., Ed.). Madison, WI, Agronomy Monograph 9.

Salt, D.E., Blaylock, M.J., Kumar, N.P.B.A., Dushenkov, V., Ensley, B.D., Chet, I., and Raskin, I. 1995. Phytoremediation: A novel strategy for the removal of toxic metals from the environment using plants. Biotechnol. 13, 468-474.

Tandy, S., Schulin, R., and Nowack, B. 2006. The influence of EDDS on the uptake of heavy metals in hydroponically grown sunflowers. Chemosphere 62, 1454-1463.

Van Engelen, D.L., Sharpe-Pedler, R.C., and Moorhead, K.K. 2007. Effect of chelating agents and solubility of cadmium complexes on uptake from soil by Brassica juncea. Chemosphere $\mathbf{6 8 ,}$ 401-408.

Vassil, A.D., Kapulnik, Y., Raskin, I., and Salt, D.E. 1998. The role of EDTA in lead transport and accumulation by Indian mustard. Plant Physiol. 117, 447-453.

Wu, J., Hsu, F.C., and Cunningham, S.D. 1999. Chelate-assisted Pb phytoremediation: Pb availability, uptake, and translocation constraints. Environ. Sci. Technol. 33, 1898-1904.

Wu, L.H., Luo, Y.M., Xing, X.R., and Christie, P. 2004. EDTA-enhanced phytoremediation of heavy metal contaminated soil with Indian mustard and associated potential leaching risk. Agr. Ecosystems Environ. 102, 307-318. 
Copyright of International Journal of Phytoremediation is the property of Taylor \& Francis Ltd and its content may not be copied or emailed to multiple sites or posted to a listserv without the copyright holder's express written permission. However, users may print, download, or email articles for individual use. 